\title{
PENGGUNAAN WHATSAPP GROUP SEBAGAI SARANA PEMBELAJARAN JARAK JAUH DI SD NEGERI TAMBAKSARI
}

\author{
Admi Isni Rifanisari*1, Badarudin*2 \\ ${ }^{1,2}$ Universitas Muhammadiyah Purwokerto
}

\begin{tabular}{l}
\hline \hline Article Info \\
\hline Article history: \\
Accepted April 22, 2021 \\
Published April, 2021 \\
\end{tabular}

\section{Keywords:}

Use of WhatsApp Group

Distance learning

\begin{abstract}
This study aims to analyze and describe learning activities using WhatsApp Group as a means of distance learning at SD Negeri Tambaksari and its obstacles. This research was conducted using a descriptive qualitative approach conducted by interviewing participants, namely teachers, guardians of students and students. The results showed that low-class teachers opened learning with greetings and high-class teachers did not open learning, material in high and low classes covered all subjects but did not fulfil all learning outcomes, the method used by low and high-class teachers was the assignment method. , the media used by low-class teachers and high-class teachers is a photo feature, assessments conducted by low-class teachers and high-class teachers in the form of online and portfolio based tests, low-class teachers and high-class teachers do not reflect, low-class teachers close learning with giving messages to students and closing greetings while high-class teachers did not close the lesson. The obstacles for teachers in learning using WhatsApp Group include limited quota, limited cellphone storage for guardians of students, teachers find it difficult to determine the method, assignments were given by the teacher through WhatsApp Group make students lazy.
\end{abstract}

Copyright $@ 2021$ FKIP UMP All right reserved

\section{Corresponding Author:}

Admi Isni Rifanisari, Badarudin

Program Studi Pendidikan Guru Sekolah Dasar

Universitas Muhammadiyah Purwokerto,

J1. KH. Ahmad Dahlan Po Box 202 Purwokerto, Banyumas, Jawa Tengah

Email: admiisnirifanisaripgsd@gmail.com badarudinbdg@gmail.com

\section{How to Cite:}

Rifanisari, A.I., Badarudin (2021). Penggunaan WhatsApp Group Sebagai Sarana Pembelajaran Jarak Jauh di SD Negeri Tambaksari. Khazanah Pendidikan-Jurnal Ilmiah Kependidikan (JIK), 15(1), 65-73. 


\section{PENDAHULUAN}

Dunia sedang menghadapi pandemi Corona Virus Disease (Covid-19) yang semakin meluas setiap harinya. Lee (2020) menyatakan pada 31 Desember 2019 muncul kasus serupa dengan pneumonia yang tidak diketahui di Wuhan, China. Kasus tersebut diakibatkan oleh virus corona atau dikenal dengan Covid-19 (Corona Virus Diesese-2019).Virus Corona juga telah mewabah di Indonesia sejak awal Maret hingga saat ini 11 November 2020 terdapat 448.118 kasus positif terkonfirmasi tersebar di 34 provinsi (Satuan Tugas Penanganan Covid-19 Indonesia). Berbagai kebijakan telah dikeluarkan pemerintah Indonesia untuk mengurangi penyebaran virus corona dengan memberlakukan social distancing, physical distancing hingga pemberlakuan PSBB (Pembatasan Sosial Berskala Besar) pada beberapa daerah sebagai beberapa strategi harapan untuk memutus rantai penularan virus corona tersebut.

Kebijakan-kebijakan yang dikeluarkan untuk membatasi penyebaran Covid-19 berdampak pada berbagai bidang di seluruh dunia khususnya pendidikan di Indonesia. Hingga akhirnya pemerintah Indonesia beserta Kementrian Pendidikan dan Kebudayaan memberlakukan Surat Edaran No. 4 Tahun 2020 (2020: 2) tentang Pelaksanaan Kebijakan Pendidikan dalam Masa Darurat Penyebaran Corona Virus Disease (Covid-19). Berdasarkan surat edaran tersebut maka diberlakukan pembelajaran dari rumah atau pembelajaran jarak jauh untuk mengurangi tersebarnya virus tersebut. Hal ini memberikan tantangan kepada semua elemen dan jenjang pendidikan untuk mempertahankan kelas tetap aktif meskipun tidak terjadi pembelajaran tatap muka.

Pembelajaran jarak jauh ini diharapkan memberikan kemudahan siswa dalam belajar dari rumah. Pembelajaran jarak jauh adalah pembelajaran yang menggunakan sarana pembelajaran yang dapat diakses menggunakan layanan internet yang memungkinkan terjadinya interaksi antara pengajar dan pembelajar yang berbeda tempat atau bahkan dengan jarak yang sangat jauh. Setyaningsih (2021:3) menyatakan bahwa pembelajaran jarak jauh adalah sistem pembelajaran yang tidak berlangsung dalam satu ruangan dan tidak terjadi suatu interaksi langsung secara tatap muka antara pengajar dan pembelajar. Sehingga pembelajaran akan tetap berlangsung hanya akan berbeda dengan pembelajaran tatap muka. McQuirter (2020: 49) menyatakan guru harus beralih dari model tatap muka ke platform online sepenuhnya dengan adanya pelatihan sebelumnya, pemodelan praktik atau dukungan teknis yang mudah diakses. Hal ini dilakukan agar pembelajaran siswa tetap bisa berlangsung dengan maksimal. Sehingga pendidik dituntut untuk berupaya memaksimalkan pembelajaran jarak jauh menggunakan sistem online, dengan menggunakan e-learning sebagai salah satu media pembelajaran dengan memanfaatkan akses internet. Di samping itu pendidik juga dipaksa untuk merubah model atau strategi pembelajaran yang biasanya diterapakan secara klasikan menjadi digital.

Ada banyak sarana yang digunakan untuk pembelajaran jarak jauh. Menurut Abidah (2020:39) Sarana yang dapat mendukung pembelajaran online yakni Google Classroom, Whatsapp, Kelas Cerdas, Zenius, Quipper dan Microsoft yang mudah diakses secara gratis digunakan oleh guru dan orang tua. Sehingga dari berbagai sarana yang mendukung pembelajaran jarak jauh tersebut, banyak akses yang dapat dilakukan guru, siswa dan orang tua dalam pembelajaran jarak jauh sesuai dengan kebutuhan dan kemampuan dalam menjalankannya. Untuk itu guru harus mengidentifikasi sarana yang sesuai untuk digunakan pada pembelajaran.

Penggunaan sarana pembelajaran ini sangatlah penting dalam proses pembelajaran jarak jauh tidak hanya sebagai pengganti pembelajaran tatap muka. Namun juga tetap memperhatikan pemahaman pada saat penyampaian pembelajaran berlangsung melalui sarana pembelajaran jarak jauh yang telah dipilih. McQuirter (2020: 50) mengatakan guru harus bersikap realistis tentang jumlah konten yang dapat di liput secara online, dan 
kemudian memilih alat yang mendukung tujuan pembelajaran online. Sehingga pada saat pembelajaran berlangsung guru harus menyesuaikan kemampuan belajar siswa dengan pembelajaran jarak jauh dengan pemberian materi dan media yang sesuai.

Pembelajaran jarak jauh yang dilakukan sekarang ini merupakan hal baru yang dilakukan oleh sekolah-sekolah, tidak hanya untuk siswa tetapi juga guru sebagai pengajar. Fullan (2020: 3) memberikan model tiga tahap untuk mendeskripsikan bagaimana sekolah beradaptasi dengan pembelajaran online, dimulai dari disruption, pindah ke transition, dan terakhir ke reimagining. Pada saat ini banyak guru yang masih dalam tahap disrupsi, berurusan dengan teknis penyampaian pembelajaran kepada siswa agar mudah diterima oleh siswa dengan berbagai latar belakang orang tua. Maka terkait hal ini guru harus tanggap mengatasi situasi untuk menggunakan sarana yang familiar digunakan oleh siswa yang masih perlu pengawasan dari orang tua. Untuk siswa tingkat sekolah dasar di kelas rendah maupun tinggi, orang tua harus mendampingi anak atau menjadi mentor dalam pelaksanakaan pembelajaran jarak jauh melalui aplikasi gawai.

Pada pembelajaran secara jarak jauh penggunaan komunikasi dengan sarana pembelajaran yang efektif dan familiar merupakan salah satu pilihan agar pembelajaran jarak jauh dapat tertangani sesuai yang diharapkan. Salah satu aplikasi yang sering digunakan dalam proses pembelajaran adalah WhatsApp. Menurut Sahidillah (2019: 54) WhatsApp memiliki fitur yang bisa menyimpan dokumen dalam bentuk $p d f$, microsoft word, excel, dan powerpoint. Maka dari itu, dengan menyimpan dokumen yang sudah diberikan melalui WhatsApp siswa dapat belajar melalui format atau bentuk yang sudah dikirim dengan mudah. Aplikasi WhatsApp ini juga memiliki fitur Group yang berisikan banyak kontak nomor untuk memudahkan berkomunikasi dengan fitur yang masih lengkap seperti mengirim gambar, voice, foto, vidio, hingga dokumen.

WhatsApp Group menjadi konten dalam aplikasi WhatsApp yang saat ini sedang populer, meskipun sebelumnya sebagian orang telah menggunakannya untuk kepentingan chat dengan para teman atau keluarga besar. Terutama pada pembelajaran jarak jauh ini dari anak usia dini hingga menengah atas. Atsani (2020: 84) menyatakan anak Sekolah Dasar (SD) juga menggunakan media-media WhatsApp Group ditambah dengan penggunaan aplikasi Zoom. Namun hal ini bukanlah hal mudah, karena tidak semua anak mampu mengoperasikan dan memiliki gawai yang mendukung adanya aplikasi WhatsApp. Namun karena fiturnya yang lengkap, WhatsApp Group ini banyak dipelajari sebagai aplikasi yang digunakan pada pembelajaran ataupun berbagi informasi terkait pembelajaran jarak jauh. WhatsApp Group yang biasanya lebih banyak menggunakan pesan text juga memberikan keringanan kuota internet bagi orang tua yang pada masa pandemi ini mengeluhkan penghasilan yang berkurang.

Penggunaan WhatsApp Group dalam pembelajaran jarak jauh memiliki manfaat yang dapat digunakan untuk aktivitas pembelajaran. Menurut Ja'far (2020: 154) dengan adanya WhatsApp Group, guru dapat mengatur alur diskusi, guru juga dapat memberi contoh mengirim pesan yang baik di dalam group, melakukan evaluasi bagi peserta didik selama proses pembelajaran. Untuk itu guru harus merancang pembelajaran yang sesuai dengan penggunaan WhatsApp Group dengan fitur yang sudah tersedia sehingga diharapkan pembelajaran akan berjalan dengan maksimal. Namun aktivitas pembelajaran menggunakan WhatsApp Group juga memiliki kendala masing-masing yang dikeluhkan oleh semua pihak baik guru, siswa dan orang tua.

Berdasarkan wawancara pada guru di SD Negeri Tambaksari, guru menyampaikan bahwa pembelajaran jarak jauh ini adalah hal baru yang dilakukan akibat adanya pandemi Covid-19 sehingga muncul kebijakan untuk siswa belajar di rumah. Dalam proses pembelajaranya guru menggunakan sarana WhatsApp Group karena dianggap mudah diaplikasikan dan semua orang tua memiliki aplikasi WhatsApp. Sejak adanya surat edaran 
pemerintah daerah terkait pembelajaran harus dilaksanakan dari rumah maka sekolah melaksanakan pembelajaran melalui WhatsApp Group dan mengumpulkan tugas secara terjadwal ke sekolah. Penggunaan WhatsApp Group ini digunakan pada semua jenjang kelas I hingga kelas VI. Dalam penggunaan WhatsApp Group ini, pembelajaran dilakukan sesuai jadwal kelasnya masing-masing. Walaupun guru, siswa dan orang tua memiliki hambatan dalam pembelajaran, namun WhatsApp Group dianggap lebih efektif digunakan dalam pembelajaran jarak jauh dibandingkan sarana yang lain.

Melalui wawancara, guru menyampaikan masih banyak kendala pada pembelajaran jarak jauh yang dialami guru, siswa dan orang tua. Meskipun sudah menggunakan sarana yang mudah dan sudah dikuasai siswa dan orang tua, namun guru menyampaikan tetap mengalami kesulitan untuk menyampaikan materi melalui WhatsApp Group agar siswa benar-benar belajar dan memahami materi yang disampaikan. Berdasarkan latar belakang yang telah diungkapkan diatas, kajian dalam penelitian ini bertujuan untuk mengetahui penggunaan WhatsApp Group sebagai sarana pembelajaran jarak jauh di sekolah yang dianggap efektif namun memiliki kendala. Sehingga, peneliti tertarik untuk meneliti bagaimana aktivitas pembelajaran menggunakan WhatsApp Group, pelaksanaan evaluasi pembelajaran dan kendala yang dialami guru dalam menggunakan WhatsApp Group sebagai sarana pembelajaran jarak jauh di SD Negeri Tambaksari.

\section{METODE}

Penlitian kualitatif menurut Creswell (2013: 14) merupakan metode untuk mengeksplorasi dan memahami makna yang oleh sejumlah individu atau sekelompok orang dianggap memiliki masalah sosial atau kemanusiaan. Hasil penelitian kualitatif ini lebih menekankan pada memberikan gambaran secara objektif tentang keadaan yang sebenarnya dari obyek yang diteliti. Penelitian ini termasuk penelitian dengan pendekatan kualitatif dan metode deskriptif, Penelitian deskriptif menurut Arikunto (2013: 36) adalah penelitian yang menggambarkan kejadian dari sebuah fenomena yang diteliti, kemudian diambil kesimpulan. Instrumen penelitian merupakan sebuah alat yang dapat digunakan untuk mengumpulkan informasi yang dilakukan pada saat penelitian di lapangan. Sugiyono (2015: 65) menyatakan bahwa dalam penelitian kualitatif, yang menjadi instrumen adalah peneliti itu sendiri. Sehingga peneliti berperan sebagai instrumen kunci dalam penelitian ini, peneliti dengan instrumen yang telah disusun berupa pedoman wawancara dan pedoman observasi akan mempermudah peneliti dalam melakukan penelitian. Peneliti mengartikan partisipan penelitian adalah sekelompok individu atau perorangan yang dijadikan informasi untuk digunakan peneliti sebagai sumber langsung dalam mendapatkan data-data yang dibutuhkan. Partisipan yang menjadi informan dalam penelitian ini yaitu guru, wali siswa dan siswa yang terdiri dari guru kelas II, III dan V, tiga wali siswa kelas II, III dan V dan tiga siswa kelas II, III dan V.

Teknik pengumpulan data dalam penelitian digunakan untuk memperoleh data yang dibutuhkan. Teknik pengumpulan data yang digunakan dalam penelitian ini adalah observasi, wawancara dan dokumentasi. Teknik analisis data yang digunakan dalam penelitian ini adalah analisis data deskriptif, artinya dari data yang diperoleh melalui beberapa metode yang digunakan kemudian diklarifikasikan dan selanjutnya analisa. Penelitian ini menggunakan analisis data model Miles dan Huberman yang terdapat 3 tahap dalam analisis data yaitu data reduction (reduksi data), data display (penyajian data), dan conclusion drawing/verification. Uji Keabsahan data dapat dilakukan dengan membuktikan mengenai penelitian yang dilakukan benar-benar merupakan penelitian ilmiah sekaligus untuk menguji data yang telah diperoleh. Untuk mengecek keabsahan data peneliti menggunakan triangulasi teknik dan triangulasi sumber. 


\section{HASIL DAN PEMBAHASAN}

Penelitian didahului dengan melakuikan observasi melalui WhatsApp Group yaitu SD Negeri Tambaksari. Berdasarkan wawancara yang diperoleh guru sudah menggunakan WhatsApp Group sejak awal pembelajaran jarak jauh, meskipun sempat melakukan inovasi dengan aplikasi lain namun WhatsApp Group dianggap paling efektif digunakan dalam pembelajaran jarak jauh dibandingkan dengan aplikasi atau media lain.

Penelitian ini mendeskripsikan tentang aktivitas pembelajaran menggunakan WhatsApp Group sebagai sarana pembelajaran jarak jauh dengan menggunakan teknik observasi, wawancara dan dokumentasi. Aktivitas pembelajaran yang dilaksanakan oleh guru menggunakan WhatsApp Group digunakan karena dianggap paling mudah digunakan oleh guru, siswa dan wal siswa.

Berdasarkan wawancara yang telah dilakukan maka peneliti menyimpulkan bahwa guru dalam menutup pembelajaran dengan memberikan pesan kepada siswa agar mengerjakan tugas dengan baik dan memberikan salam. Langkah-langkah pembelajaran jarak jauh secara daring menurut Kemendikbud, Surat Edaran Nomor 15 Tahun 2020 (2020: 10) yaitu: (1). Periksa kehadiran peserta didik dan pastikan peserta didik siap mengikuti pembelajaran. (2). Mengajak peserta didik berdoa sebelum dan sesudah pembelajaran. (3). Penyampaian materi sesuai dengan metode dengan metode yang digunakan. (4). komunikasi dengan orang tua/wali peserta didik atau peserta didik terkait penugasan belajar (5). Selalu berikan kesempatan pada peserta didik untuk bertanya, mengemukakan pendapat, dan/atau melakukan refleksi.

Empat langkah ini sebagaimana yang diterangkan Kemendikbud merupakan langkahlangkah yag harus dipenuhi dalam pembelajaran jarak jauh menggunakan WhatsApp group, berdasarkan pemaparan Kemendikbud pada Surat Edaran Nomor 15 Tahun 2020 dinyatakan langkah yang pertama membuka pembelajaran dengan periksa kehadiran peserta didik dan pastikan peserta didik siap mengikuti pembelajaran serta mengajak peserta didik berdoa sebelum pembelajaran. Pada saat melakukan observasi dan wawancara guru pada kelas rendah guru membuka pembelajaran dengan memberikan salam dan menanyakan kabar siswa sedangkan pada kelas tinggi guru tidak membuka pembelajaran.

Langkah yang kedua berdasarkan pemaparan Kemendikbud pada Surat Edaran Nomor 15 Tahun 2020 adalah Penyampaian materi sesuai dengan metode yang digunakan. Guru di SD Negeri Tambaksari berdasarkan keterangan yang telah didapatkan guru menyampaikan materi dengan tidak membebankan semua kompetensi harus terselesaikan sehingga guru memberikan materi yang sedikit namun siswa memahami materi tersebut, sedangkan untuk metode yang di gunakan guru setiap pembelajaran selalu sama yaitu dengan memberikan materi dan tugas saja karena dengan adanya metode lain tidak memungkinkan. Siswa tidak memiliki Handphone sendiri sehingga guru tidak bisa melakukan metode yang lain.

Langkah yang ketiga berdasarkan pemaparan Kemendikbud pada Surat Edaran Nomor 15 Tahun 2020 adalah komunikasi dengan orang tua/wali peserta didik atau peserta didik terkait penugasan belajar. Guru di SD Negeri Tambaksari berdasarkan observasi dan wawancara yang dilakukan, evaluasi yang diberikan guru berupa tes dengan bentuk soal objektif dan subjektif, selain itu guru juga memberikan tugas portofolio dengan pada kelas rendah menggambar atau menyanyi sedangkan kelas tinggi dengan mencatat materi. Guru juga berkoordinasi melalui WhatsApp group dengan mengingatkan kepada wali siswa atau siswa untuk mengumpulkan tugas tersebut bila sudah melewati waktu yang ditentukan.

Langkah yang keempat berdasarkan pemaparan Kemendikbud pada Surat Edaran Nomor 15 Tahun 2020 adalah selalu berikan kesempatan pada peserta didik untuk bertanya mengemukaan pendapat dan atau melakukan refleksi. Guru di SD Negeri Tambaksari berdasarkan observasi dan wawancara yang telah dilakukan, guru kelas rendah dan guru kelas tinggi tidak melakukan tanya jawab atau refleksi pada pembelajaran melalui WhatsApp 
Group. Apabila terjadi tanya jawab, guru hanya menanyakan apabila ada kesulitan bisa ditanyakan namun siswa tidak ada yang bertanya.

Langkah yang keempat berdasarkan pemaparan Kemendikbud pada Surat Edaran Nomor 15 Tahun 2020 adalah menutup pembelajaran dengan berdoa. Guru di SD Negeri Tambaksari pada kelas rendah menutup pembelajaran dengan salam dan memberikan semangat kepada siswa untuk belajar. Sedangkan pada kelas tinggi tidak menutup pembelajaran. Dari wawancara yang dilakukan maka dapat disimpulkan bahwa kendala yang dialami guru dalam pembelajaran menggunakan WhatsApp Group diantaranya kuota yang terbatas sehingga pada saat pengiriman materi yang membutuhkan kuota yang banyak akan memberikan kendala bagi guru untuk memberikan materi, penyimpanan gawai orang tua yang terbatas sehingga materi yang diberikan tidak bisa yang terlalu besar dan membutuhkan ruang yang banyak, sulit menentukan metode yang sesuai dengan kondisi siswa karena gawai di bawa kerja orang tua, tugas yang diberikan melalui WhatsApp Group membuat siswa malas dan menunda pekerjaan sehingga pengumpulanya selalu terlambat. Hal ini tentunya tidak dapat sepuhnya diatasi karena memang pembelajaran jarak jauh ini setiap walisiswa dan siswa memiliki kemampuan yang berbeda-beda untuk mendukung pembelajaran jarak jauh meskipun sudah menggunakan aplikasi WhatsApp yang sudah dianggap paling efektif digunakan dalam pembelajaran.

Aktivitas pembelajaran menggunakan sarana WhatsApp group dalam pembelajaran jarak jauh di SD Negeri Tambaksari yang dilakukan guru pada pembelajaran jarak jauh tentunya sangat berbeda dengan pembelajaran tatap muka di sekolah. Guru harus menyesuaikan diri menggunakan sarana-sarana yang sesuai untuk digunakan dalam pembelajaran jarak jauh. SD Negeri Tambaksari menggunakan WhatsApp group sebagai sarana pembelajaran jarak jauh, meskipun sebelumnya guru mengupayakan sarana lain untuk digunakan namun guru beserta orang tua sepakat untuk menggunakan WhatsApp Group yang lebih mudah digunakan dan dimiliki semua wali siswa atau siswa. Guru, wali siswa dan siswa menyatakan bahwa WhatsApp Group dapat dipahami besrta dengan penggunaan Fitur-fiturnya.

Langkah-langkah pembelajaran jarak jauh secara daring menurut Kemendikbud, Surat Edaran Nomor 15 Tahun 2020 (2020: 10) yaitu: (1). Periksa kehadiran peserta didik dan pastikan peserta didik siap mengikuti pembelajaran; (2). mengajak peserta didik berdoa sebelum dan sesudah pembelajaran; (3). penyampaian materi sesuai dengan metode dengan metode yang digunakan; (4) komunikasi dengan orang tua/wali peserta didik atau peserta didik terkait penugasan belajar; (5). selalu berikan kesempatan pada peserta didik untuk bertanya, mengemukakan pendapat, dan/atau melakukan refleksi. Guru di SD Negeri Tambaksari berdasarkan pada Kemendikbud, Surat Edaran Nomor 15 Tahun 2020 belum melaksanakan semua kelima tahapan aktivitas pembelajaran tersebut. Berdasarkan observasi dan wawancara yang telah dilakukan diketahui bahwa terdapat beberapa tahap yang tidak dilakukan oleh guru. Pada membuka pembelajaran guru kelas rendah memberikan salam dan menanyakan kabar siswa. Sedangkan pada kelas tinggi guru tidak membuka pembelajaran guru menyatakan absensi kehadiran didapatkan dengan cara siswa mengumpulkan tugastugas yang telah diberikan. Sesuai pernyataan Kemendikbud, Surat Edaran Nomor 15 Tahun 2020 (2020: 10) guru periksa kehadiran peserta didik dan pastikan peserta didik siap mengikuti pembelajaran. Dalam hal ini guru hanya mengecek kehadiran siswa melalui tugas yang dikumpulkan saja.

Materi yang diberikan guru baik di kelas rendah maupun kelas tinggi melalui WhatsApp Group di SD Negeri Tambaksari adalah semua mata pelajaran dengan pemberian yang tidak menuntaskan semua capaian yang ada. Hal ini sesuai dengan berdasarkan surat edaran Mendikbud Nomor 4 (2020:1), bahwa Guru memberikan pengalaman belajar yang bermakna bagi siswa, tanpa terbebani tuntutan menuntaskan seluruh capaian kurikulum 
kenaikan kelas maupun kelulusan. Berdasarkan hal ini guru hanya memberikan materi sedikit namun siswa mampu memahami materi yang disampaikan dengan pendampingan dari wali siswa. Metode yang digunakan oleh guru di kelas rendah dan kelas tinggi dalam pembelajaran menggunakan sarana WhatsApp Group di SD Negeri Tambaksari adalah dengan memberikan materi dan penugasan. Guru menggunakan metode ini karena adanya kendala diantaranya gawai yang digunakan untuk belajar siswa adalah milik orang tua yang tentunya di bawa orang tua sehingga guru tidak memungkinkan menggunakan metode lain saat pembelajaran menggunakan WhatsApp Group.

Media yang digunakan oleh guru kelas rendah dan kelas tinggi dalam pembelajaran menggunakan sarana WhatsApp Group di SD Negeri Tambaksari adalah memanfaatkan fitur yang ada di WhatsApp Group yaitu mengirimkan foto. Guru menggunakan fitur ini untuk mengirimkan materi atau tugas. Guru menyatakan penggunaan fitur ini memudahkan siswa dalam memahami materi dengan langsung membaca materi melalui WhatsApp Group. Dengan mengeluhnya kuota yang tidak terlalu banyak dan penyimpanan gawai yang sedikit diharapkan dengan memanfaatkan fitur foto ini siswa dapat belajar dengan maksimal.

Evaluasi yang digunakan oleh guru dalam pembelajaran menggunakan sarana WhatsApp Group di SD Negeri Tambaksari adalah evaluasi dalam bentuk tes baik tes objektif dalam bentuk pilihan ganda dan tes subjektif dalam bentuk essay. Guru di kelas rendah memberikan portofolio dengan memberikan tugas dalam bentuk menyanyi atau menggambar sedangkan guru di kelas tinggi mencatat materi yang telah diberikan. Sependapat dengan Ahmad (2020: 210-217) menyatakan ada beberapa model assesmen yang dapat diterapkan dalam pembelajaran jarak jauh diantaranya tes berbasis daring berupa tes subjektif dan tes objektif, portofolio berupa produk nyata yang dihasilkan oleh siswa agar guru mengetahui perkembangan kemampuan yang dimiliki siswa.

Pada aktivitas pembelajaran tanya jawab dan refleksi, guru menyatakan tidak melakukan hal tersebut karena pembelajaran hanya menyampaikan materi dan tugas saja. Namun menurut Sosia (2019) menyatakan bahwa siswa sekolah dasar kelas rendah menyukai umpan balik melalui gambar dan smiley yang ada di fitur WhatsApp karena dianggap lebih menarik. Sedangkan siswa kelas tinggi menyukai umpan balik dalam bentuk tertulis karena mereka lebih menerima lebih banyak informasi lebih banyak dengan tulisan. Guru kelas rendah dan guru kelas tinggi hanya menanyakan kepada siswa apabila ada hal yang sulit bisa ditanyakan.

Menutup pembelajaran oleh guru dalam pembelajaran menggunakan sarana WhatsApp Group di SD Negeri Tambaksari dengan memberikan salam dan mengucapkan terimakasih atas perhatian dan kerjasama dengan wali siswa dan siswa. Namun menurut Kemendikbud, Surat Edaran Nomor 15 Tahun 2020 (2020: 10) dalam menutup pembelajaran guru memberikan petunjuk untuk berdoa setelah pembelajaran selesai. Sedangkan guru kelas tinggi tidak menutup pembelajaran pada pembelajaran menggunakan WhatsApp Group. Dalam pembelajaran jarak jauh menggunakan WhatsApp Group tentunya guru mengalami beberapa kendala diantaranya kuota wali siswa atau siswa yang terbatas menjadi kendala guru dalam menyampaikan pembelajaran. Pada saat mengirimkan materi dengan vidio atau dalam bentuk lain yang membutuhkan kuota yang banyak wali siswa mengeluhkan pengeluaran kuota. Melalui wawancara yang telah dilakukan guru menyampaikan dengan kendala ini materi yang diberikan melalui WhatsApp Group menggunakan fitur berbagi foto. Penyimpanan gawai wali siswa/ orang tua yang terbatas. sehingga materi yang dikirimkan tidak memiliki kapasitas yang terlalu besar dan membutuhkan ruang penyimpanan yang banyak. Guru SD N Tambaksari menyatakan guru tidak memberikan materi dengan memberikan vidio yang memiliki kapasitas yang besar. Selain karena penyimpanan yang besar juga WhatsApp Group ini hanya bisa membagikan vidio dalam kapasitas tertentu. Seperti yang disampaikan Saragih (2020: 209) bahwa WhatsApp Group terdapat maksimum 
kapasitas dokumen atau vidio yang bisa dibagikan. Jadi guru perlu memperhatikan apabila akan mengirimkan vidio melalui WhatsApp Group.

Sulit menentukan metode pembelajaran. Dari hasil wawancara yang telah dilakukan guru ksulitan menentukan metode yang digunakan karena gawai yang di bawa wali siswa sehingga pembelajaran yang dilakukan hanya membagikan materi dan tugas saja yang terpenting siswa bisa memplajari materi yang disampaikan. Guru sudah berusaha menggunakan fitur yang ada di WhatsApp group untuk mempermudah metode yang digunakan. Hal ini sesuai dengan pernyataan Barhomi (dalam Jumiatmoko 2016: 55) bahwa informasi dan pengetahuan dapat dengan mudah dibuat dan disebarluaskan melalui berbagai fitur WhatsApp group. Tugas yang diberikan melalui WhatsApp Group membuat siswa malas dan menunda pekerjaan sehingga pengumpulanya selalu terlambat. Melalui wawancara yang dilakukan dengan guru, hal ini diatasi dengan selalu mengingatkan kepada siswa dan memberikan list nama-nama yang sudah atau belum mengumpulkan tugas sehingga mmotivasi siswa. Hal ini sesuai dengan pernyataan Shodiq (2020: 155) bahwa guru secara berkesinambungan memberikan motivasi terhadap hasil kinerja siswa sekalipun hasilnya belum maksimal.

\section{KESIMPULAN}

Aktivitas pembelajaran melalui sarana WhatsApp Group dalam pembelajaran jarak jauh sudah berjalan sesuai kondisi dan situasi yang sedang terjadi pada masa pandemi Covid19. Guru memanfaatkan WhatsApp Group sebagai sarana pembelajaran jarak jauh. Aktivitas yang terjadi dalam pembelajaran jarak jauh melalui WhatsApp Group di SD Negeri Tambaksari sesuai dengan langkah-langkah pembelajaran jarak jauh daring oleh guru maka aktivitas pembelajaran yang dilakukan guru menggunakan WhatsApp Group diantaranya guru kelas rendah membuka pembelajaran dengan salam dan guru kelas tinggi tidak membuka pembelajaran, materi yang disampaikan pada kelas tinggi dan kelas rendah mencakup semua mata pelajaran namun tidak memenuhi semua capaian pembelajaran, metode yang digunakan oleh guru kelas rendah dan kelas tinggi adalah metode penugasan dengan memberikan materi dan tugas, media yang digunakan oleh guru kelas rendah dan guru kelas tinggi adalah fitur foto dengan memberikan materi dan tugas, penilaian yang dilakukan guru kelas rendah dan guru kelas tinggi dengan memberikan tes berbasis daring dan portofolio, Guru kelas rendah dan guru kelas tinggi tidak melakukan refleksi dan guru kelas rendah menutup pembelajaran dengan memberikan pesan kepada siswa dan salam penutup sedangkan guru kelas tinggi tidak menutup pembelajaran.

Kendala yang dialami guru dalam pembelajaran menggunakan WhatsApp group diantaranya kuota yag terbatas sehingga guru hanya memberikan materi melalui dan tugas melalui foto, penyimpanan Handphone orang tua yang terbatas menajdikan guru memberikan pembelajaran yang tidak mengharuskan siswa mendownload materi dengan jumlah penyimpanan yang terllu banyak, guru sulit menentukan metode yang sesuai dengan kondisi siswa atau wali siswa sehingga guru hanya menggunakan metode materi dan penugasan dan tugas yang diberikan guru melalui WhatsApp Group membuat siswa malas dan menunda pengerjaanya shingga guru selalu memotivasi siswa dengan mengelist namanama yang belum mengumpulkan tugas. 


\section{DAFTAR PUSTAKA}

Abidah, A., et. all. (2020). The Impact of COVID-19 to Indonesian Education and Its Relation to the Philosophy of "Merdeka Belajar" Studies in Philosophy of Science and Education. Journal Studies in Philosophy of Science and Education, 1(1): 38-49.

Ahmad, I. F. (2020) Asesmen Alternatif falam Pembelajaran Jarak Jauh Pada Masa Darurat Penyebaran Coronavirus Disease (Covid-19) Di Indonesia. Jurnal Pedagogik, 07 (01): 192-222

Arikunto. S. (2013). Prosedur Penelitian Pendekatan Praktik. Jakarta: Rineka Cipta.

Atsani, Lalu Gede Muhammad. (2020). Transformasi Media Pembelajaran Pada Masa Pandemi COVID-19. Jurnal Studi Islam, 1 (1): 82-93.

Creswell. J.W. (2013) Research Desaign: Pendekatan Kualitatif, Pendekatan Kuantitatif dan Mixed. Yogyakarta: Pustaka Pelajar

Fullan, M., et. all. (2020). Education Reimagined: The future of Learning- A collaborative position paper between New Pedagogies for Deep Learning and Microsoft Education. A Position Paper On A Paradigm Shift For Education, 1-34

Jumiatmoko. (2016). WhatsApp Mesengger Dalam Tinjauan Manfaat dan Adab. Jurnal Wahana Akademika, 3 (1): 52-66

Lee, a. (2020). Wuhan novel coronavirus (COVID-19): why global control is. Journal Public Health, 10-21.

McQuirter, R. (2020) Lessons on Change: Shifting to Online Learning During COVID-19. A journal of educational research and practice, 29 (2) 47-51

Kemendikbud. (2020). Surat Edaran Nomor 4 Tahun 2020 Tentang Pelaksanaan Kebijakan Pendidikan Dalam Masa Darurat Penyebaran Corona Virus Disease (Covid-19). Jakarta: Kementrian Pendidikan dan Kebudayaan.

Kemendikbud. (2020). Surat Edaran Nomor 15 Tahun 2020 Tentang Penyelenggaraan Dari Rumah Dalam Masa Darurat Penyebaran Corona Virus Disease (Covid-19). Jakarta: Kementrian Pendidikan dan Kebudayaan.

Satuan Tugas Penanganan COVID-19. Infografis COVID-19 (11 November 2020). (2020). Diakses pada 11 November, 2020, dari website https://covid19.go.id/p/berita/infografis-COVID-19-11-november-2020: Satuan Tugas Penanganan COVID-19 (2020)

Sahidillah M.K, dkk. (2019). Whatsapp Sebagai Media Literasi Digital Siswa. Varia Pendidikan, 31 (1), 52-57

Saragih, E.M., dkk. (2020). Efektivitas Penggunaan Whatsapp Group Selama Pandemi Covid-19 Bagi Pelaku Pendidik. Prosiding Seminar Nasional Multidisiplin Ilmu Universitas Asahan ke-4 Tahun 2020: 207-212

Setyaningsih, K.D., Eka, I. K., \& Badarudin. (2020). Analisis Pelaksanaan Pembelajaran Jarak Jauh Di Sd Negeri Karangrena 03. Jurnal Riset Pendidikan Dasar (JPRD), 1 (1), $19-27$

Shodiq, I J, dkk. (2020). Pemanfaatan Media Pembelajaran E-Learning Menggunakan Whastsapp Sebagai Solusi Ditengah Penyebaran Covid-19 di MI Nurulhuda Jelu. Jurnal Studi Keislaman, 6 (2), 144-159

Sugiyono. (2015). Metode Penelitian: Pendekatan Kuantitatif, kualitatif, dan $R \& D$. Bandung. Alfabeta.

Sosia, S., et. all. (2020). Feedback and Mobile Instant Messaging: Using WhatsApp as a Feedback Tool in EFL. International Journal of Instruction, 13(01): 797-812

WhatsApp, Inc: Fitur WhatsApp. (2020). Diakses 25 November, 2020, dari website https://www.whatsapp.com/features/?lang=id: WhatsApp, Inc (2020) 